\title{
Study of Load-Settlement and Consolidation Behavior of Pond Ash and Stone Dust Column Installed In Soft Clayey-Silt Soil
}

\author{
Sadrita Dutta ${ }^{\# 1}$, Dr. Sujit Kumar Pal ${ }^{\# 3}$ \\ Civil Engineering Department, N.I.T Agartala, Tripura, India \\ 1'sadrita87dutta@gmail.com \\ 3 skpal1963@gmail.com
}

\begin{abstract}
An attempt is made to use pond ash and stone dust (stone passing through 600 micron) to form column that will be installed into soft soil. The column made of pond ash and stone dust is stiffer and stronger than the original soil. The properties of soil, pond ash and stone dust are determined in the laboratory. Load test on column installed in clayey-silt soil is conducted by varying the loading plate size through which load is applied on soil column system. The diameter of the column is $20 \mathrm{~mm}$ and the length is taken as $200 \mathrm{~mm}$. A tank of size $320 \mathrm{~mm} \times 320 \mathrm{~mm} \times 400 \mathrm{~mm}$ is used of as model testing tank. Test is conducted at liquid limit $(=\mathbf{4 5 \%})$ and water content maintained throughout the tests in the range of 45 $46 \%$. Bulging depth of the pond ash column and stone dust column installed in soft soil is also determined after each loading test. For understanding of consolidation behavior of the soil column system consolidation tests are conducted in laboratory. The effects of pond ash and stone dust used as column on load-settlement behavior and consolidation characteristics are also premeditated. Test results show that column made of stone dust is better than pond ash for soft clayey-silt soil.
\end{abstract}

Key words: Soft soil, pond ash, stone dust, load-settlement behavior and loading plate.

\section{INTRODUCTION}

There are different ground improvement techniques available in geotechnical engineering field. Installations of stone columns are found to be effective and economical ground improvement technique for soft soils. A number of pioneering works on stone column are carried out by various researchers; there are some field records. Reference [1] carried out experimental studies to evaluate the behavior of stone column by varying spacing, shear strength of soft clay, moisture content and loading condition; the results obtained were analyzed using the finite element package PLAXIS. Result also shows the load-settlement behavior and was almost linear for entire area loading and failure was by bulging of the column with maximum bulging at $0.50 \mathrm{~d}$ to $1.00 \mathrm{~d}$, where $\mathrm{d}$ is the diameter of column. A detailed experimental study carried out by [2] on the behavior of single column and group of seven columns by varying parameters like, spacing between the columns, shear strength of soft clay, and loading. Load tests were performed on single un-encased as well as on encased stone column to study the effect of diameter on the capacity of column [3]. A series of plate load tests on isolated stone columns installed in a soil bed had shown that the settlement characteristics of the soil can be improved by installing stone columns and that a significant enhancement in the load-settlement response was achieved when the columns were reinforced by the various methods [4]. Reference [6] conducted laboratory model tests to study the behavior of stone column both encased with geotextile and without encasement in local soft and loose layered soil. They found that in case of un-encasement, bearing capacity of soil increased with the increase of diameter of stone column; whereas bearing capacity decreased with increase of diameter for encasement. Experimental studies were carried out on single sand columns having a length of $15 \mathrm{~cm}$ and a diameter ranging from 12.50 to $38.00 \mathrm{~mm}$ in soft kaolin clay and loaded in stages [8]; results show that presence of sand columns accelerated the rate of settlement by four times and reduced the vertical displacement by six times. Reference [9] carried out a plate load test on stone column of $0.66 \mathrm{~m}$ diameter in $7.00 \mathrm{~m}$ thick soft soil to study the effect of stone column in soil. Reference [10] compared between the bearing capacity of the natural and reinforced clay as measured using plate load test indicated that the bearing capacity for reinforced clay was improved by a factor between 2.50 and 4.00, and the design guidelines of stone column for construction on soft clay soils and their performance are emphasized. The paper also presented the results from a laboratory based studies on the performance of the encased stone columns both woven and non-woven. The qualitative and quantitative improvement of individual load capacity of stone column with encasement through laboratory model tests were conducted on stone columns installed in clay bed prepared in a large testing tank [11]. Load tests on stone columns having diameters of 25,50 , and $75 \mathrm{~mm}$ were conducted applying load to the column through a circular steel plate of diameter equal to 1.50 times that of the column as reported by [12] and the results of the tests 
indicated that stone columns transfer the load to the surrounding clay through bulging action which helps in mobilizing the passive resistance of the surrounding clay. Till date stone column have been studied by many researchers as well as scientists. It is a pre-requisite to study the properties stone column, sand column which are in use today for developing a column with new material other than stone. In the present study special attention is given to the stone column technique to improve soft soils. An attempt has been made to use pond ash and stone dust (passing through 600 micron) to form columns which installed into soft clayey-silt soil. In this study clayey-silt soils are mixed with water at liquid limit. That is why this clayey-silt soil is considered as soft soil. These types of small column provide reinforcement and drainage facility to the soft clayey-silt soil and improve the strength and deformation properties of this soil. The existence of the column generates a composite material that is stiffer and stronger than the original surrounding soil.

\section{A. Materials and Experimental Programme}

\section{DESCRIPTION OF LABORATORY MODEL TESTS}

Three types of material are used in this study i.e., pond ash, stone dust (stone passing through 600 micron) and clayey-silt soil. The physical and engineering properties of these materials are evaluated in laboratory by conducting various laboratory tests. Table 1 shows the properties of pond ash, stone dust and clayey-silt soil. In the present study a unit cell model is used. Generally, in the field there are numbers of columns installed in the soil. In that case centrally placed column is generally considered as unit cell and the same concept implemented when test conducted in the laboratory using single column installed in soil within the testing tank. This is called as unit cell concept. References [1, 2, 5, 7 and 13] have used the unit cell tank in their laboratory model tests. To make the simple design of apparatus and assess the behavior of column made of pond ash and stone dust a rectangular tank is used. To avoid the effect of boundaries of the testing tank on loading a size of $320 \mathrm{~mm} \times 320 \mathrm{~mm} \times 400 \mathrm{~mm}$ (height) testing tank is used to represent the unit cell area. The diameter of the columns used for model test is $20 \mathrm{~mm}$ and the length of each column is $200 \mathrm{~mm}$. The column is installed at centre of the tank installed in soft clayey-silt soil as shown in Fig. 1. Load is applied on single column in three ways:

1. Through loading plate of diameter equal to column diameter;

2. Through loading plate of diameter equal to twice the column diameter; and

3. Entire area loading (i.e., size of square loading plate is $300 \mathrm{~mm} \times 300 \mathrm{~mm}$ ).

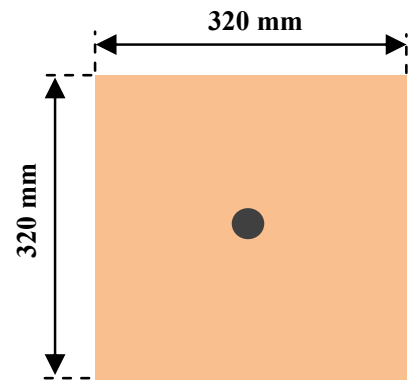

Fig. 1. Single column installed in soft clayey-silt soil in testing tank

TABLE I. Properties of pond ash, stone dust and clayey-silt soil

\begin{tabular}{lccc}
\hline Properties & Test Results & \\
& Pond ash & Stone dust & Clayey-silt soil \\
\hline Sand size $(0.075 \mathrm{~mm}-2.00 \mathrm{~mm}),(\%)$ & 20.00 & 45.00 & 2.00 \\
Silt size $(0.002 \mathrm{~mm}-0.075 \mathrm{~mm}),(\%)$ & 73.00 & 41.50 & 53.00 \\
Clay size $(<0.002 \mathrm{~mm}),(\%)$ & 7.00 & 13.50 & 45.00 \\
Specific gravity $(\mathrm{G})$ & 2.22 & 2.48 & 2.61 \\
Liquid limit, LL $(\%)$ & Non-plastic & - & 45.00 \\
Plastic limit, PL $(\%)$ & Non-plastic & - & 21.00 \\
Plasticity index, PI $(\%)$ & Non-plastic & - & 24.00 \\
Compression index, $\mathrm{C}_{\mathrm{c}}$ & 0.119 & - & 0.227 \\
Coefficient of compressibility, $\mathrm{a}_{\mathrm{v}}\left(\mathrm{m}^{2} / \mathrm{kN}\right)$ & $4.50 \times 10^{-5}$ & - & $8.55 \times 10^{-5}$ \\
Coefficient of volume change, $\mathrm{m}_{\mathrm{v}}\left(\mathrm{m}^{2} / \mathrm{kN}\right)$ & $2.40 \times 10^{-5}$ & - & $4.70 \times 10^{-5}$ \\
Coefficient of consolidation, $\mathrm{c}_{\mathrm{v}}\left(\mathrm{m}^{2} / \mathrm{min}\right.$.) & $1.21 \times 10^{-4}$ & - & $3.26 \times 10^{-4}$
\end{tabular}


Water absorption (\%)

$\begin{array}{ccc}- & 0.97 & - \\ 0.30 & 0.22 & 37.20 \\ 15.20 & 17.43 & 6.70 \\ & & \\ 32.40 & - & 24.50 \\ 11.50 & 18.50 & 15.60 \\ 1.67 \times 10^{-5} & - & 4.74 \times 10^{-8}\end{array}$

Cohesion, c $(\mathrm{kPa})$

Angle of internal friction, $\phi$ (in degree)

Standard Proctor compaction :

Optimum moisture content. OMC (\%)

Maximum dry density, MDD $\left(\mathrm{kN} / \mathrm{m}^{3}\right)$

$1.67 \times 10^{-5}$

$4.74 \times 10^{-8}$

\section{B. Preparation of Clayey-Silt Soil Bed and Installation of Column}

The soft clayey-silt soil is mixed thoroughly with water at liquid limit of $45 \%$. A $50 \mathrm{~mm}$ bed is prepared by compacted sand. The tank is filled with soil water slurry surrounding the column in five layers up to length equal to the column length. . A uniform compaction is given to each layer of soil water slurry in testing tank to achieve a uniform density of $14.7 \mathrm{kN} / \mathrm{m}^{3}$ at liquid limit. A column is installed at the center of the tank by displacement method. A casing pipe having an inner diameter equal to diameter of the column and $2 \mathrm{~mm}$ thickness is used to form the column. The casing pipe is placed at the centre position on the soil bed. After positioning the casing pipe the premeasured amount of materials used to form column is poured into pipe in 3 layers by continuous lifting of the pipe to form the column. Each layer is compacted with 25 numbers of blows with tamping rod. Subsequently, the tank is filled by pouring the estimated amount of soft clayey-silt soil-water slurry in five layers. The top surface of the column is leveled properly. After that the tank is kept in close room for a period of 1 to 2 days. The moisture content of the testing tank is maintained in the range of $45-46 \%$. In the testing tank drainage facility is provided. For every load test, the clayey-silt soil bed is to be laid down afresh in same manner. The plan area of the tank is preferred in such a way that the effect of tank boundaries on loading system has no effect. Column of pond ash and stone dust (stone passing through 600 micron) used is shown in Fig. 2.
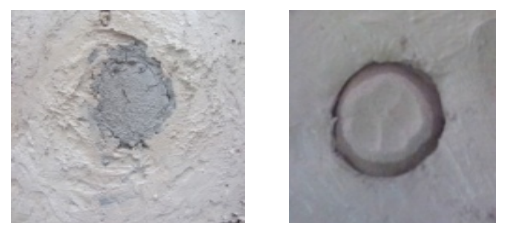

Fig. 2. Single columns of different materials used and installed in soft clayey-silt soil

\section{Load Test on Column}

After finishing the installation programme of the column, the entire tank along with soil-column system is placed on Compression Testing Machine is shown in Fig. 4. The column is subjected to vertical load through loading plate of various sizes as mentioned earlier for load-settlement test. Loading test is shown in Fig. 3. The thickness of all the loading plates is $10 \mathrm{~mm}$. The settlement in the column is measured with the help of a dial gauge of accuracy $0.01 \mathrm{~mm}$ at suitable intervals and the load is measured through a proving ring of capacity 5 $\mathrm{kN}$.

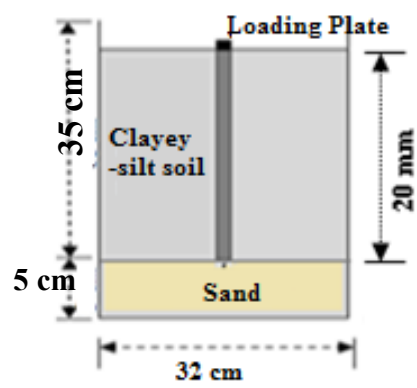

(a) Plate size equal to diameter of column

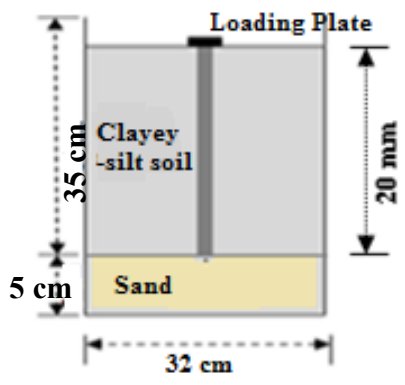

(b) Plate size equal to twice the diameter of column

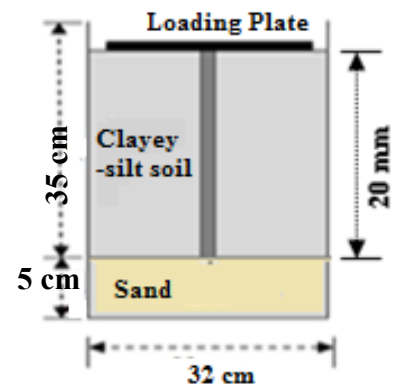

(c) Plate size equal to $300 \mathrm{~mm} \times$ $300 \mathrm{~mm}$ square

Fig. 3. Schematic diagram of the load test on columns in a testing tank 

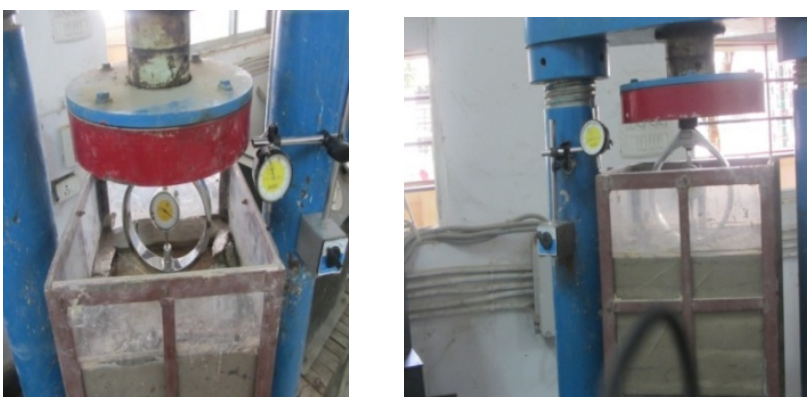

Fig. 4. Load test on column in Compression Testing Machine

\section{RESULTS}

In laboratory, total 12 numbers tests are carried out for both load test and consolidation on single columns installed in soft clayey-silt soil, in which 9 numbers of tests for load-settlement behavior and 3 numbers of tests for consolidation behavior of soil-column system.

A. Load -settlement test:

The load-settlement tests for single column are carried out on column up to a maximum settlement of $40 \mathrm{~mm}$. The values of load carried by column using pond ash and stone dust (stone passing through 600 micron) corresponding to a settlement of $40 \mathrm{~mm}$ are in the range of 0.374 to $1.017 \mathrm{kN}$ and 0.473 to $1.547 \mathrm{kN}$ respectively for all the three sizes of loading plate of this study. Loads carried by clayey-silt soil alone without any column is in the range of 0.309 to $0.950 \mathrm{kN}$ for all the three sizes of loading plate. Details are shown in Table 2 .

\section{B. Consolidation test}

To understand the consolidation behavior of soil-column system consolidation tests are carried out in laboratory. These tests are carried out at liquid limit of $45 \%$. Table 3 shows the consolidation properties of soft clayey-silt soil and column of different materials installed in soft clayey-silt soil.

TABLE II. Values of load carried by single column and clayey-silt soil at $40 \mathrm{~mm}$ settlement

\begin{tabular}{|c|c|c|c|c|}
\hline \multirow{3}{*}{ Materials } & \multirow{3}{*}{$\begin{array}{l}\text { Diameter }(d) \text { of } \\
\text { column } \\
(\mathbf{m m})\end{array}$} & \multicolumn{2}{|c|}{ Diameter of loading plate (mm) } & \multirow{2}{*}{$\begin{array}{c}\begin{array}{c}\text { Size of square loading } \\
\text { plate }(\mathbf{m m})\end{array} \\
\mathbf{3 0 0} \times \mathbf{3 0 0}\end{array}$} \\
\hline & & d & 2d & \\
\hline & & \multicolumn{3}{|c|}{ Load carried by single column $(\mathrm{kN})$} \\
\hline Pond ash & 20 & 0.374 & 0.504 & 1.017 \\
\hline Stone dust & 20 & 0.473 & 0.669 & 1.547 \\
\hline Clayey-silt & without column & 0.309 & 0.444 & 0.950 \\
\hline
\end{tabular}

TABLE III. Values of consolidation characteristics and void ratio of column made of pond ash, stone dust, and clayey-silt soil

\begin{tabular}{llll}
\hline Properties & \multicolumn{3}{c}{ Test results } \\
\cline { 2 - 4 } & $\begin{array}{l}\text { Pond ash } \\
\text { column }\end{array}$ & $\begin{array}{l}\text { Stone dust } \\
\text { column }\end{array}$ & $\begin{array}{l}\text { Clayey-silt } \\
\text { soil }\end{array}$ \\
\hline Compression index, $\mathrm{C}_{\mathrm{c}}$ & 1.567 & 1.366 & 1.606 \\
Coefficient of compressibility, $\mathrm{a}_{\mathrm{v}}\left(\mathrm{m}^{2} / \mathrm{kN}\right)$ & $1.440 \times 10^{-4}$ & $1.226 \times 10^{-4}$ & $1.488 \times 10^{-4}$ \\
Coefficient of volume change, $\mathrm{m}_{\mathrm{v}}\left(\mathrm{m}^{2} / \mathrm{kN}\right)$ & $1.07 \times 10^{-5}$ & $7.54 \times 10^{-5}$ & $1.15 \times 10^{-4}$ \\
Coefficient of consolidation, $\mathrm{c}_{\mathrm{v}}\left(\mathrm{m}^{2} / \mathrm{min}\right)$ & $3.31 \times 10^{-5}$ & $5.89 \times 10^{-5}$ & $2.62 \times 10^{-5}$ \\
Void ratio, e & 0.683 & 0.728 & 0.624 \\
\hline
\end{tabular}

Note: Compression index reported in table 1 is for individual materials at OMC obtained by Standard Proctor test used in this study. In table 3 the values of the compression index of the clayey-silt soil with stone dust and pond ash column, and clayey-silt soil without column at liquid limit are reported. 


\section{DISCUSSIONS}

Load tests and consolidation tests are carried out on columns made of pond ash and stone dust installed in soft clayey-silt soil in testing tank. Effects of materials, size of the loading plates, failure surface and consoilidation characteristics (i.e., $\mathrm{C}_{\mathrm{c}}$, and $\mathrm{c}_{\mathrm{v}}$ ) are discussed herein.

\section{A. Effect of materials of columns on clayey-silt soil}

Different materials are used to form column i.e., pond ash and stone dust (stone passing through 600 micron). Figure 5 shows the effect of material on load-settlement behavior of soil-column system using single column in testing tank. In the laboratory test result on single column it is seen that stone dust (passing through 600 micron) column improves the bearing capacity of soft clayey-silt soil more than that of column made of pond ash in clayey-silt soil. This may be due to stiffness of the materials used in this study. The stiffness ratio of the stone dust and pond ash are $0.0164 \mathrm{kN} / \mathrm{mm}$ and $0.0110 \mathrm{kN} / \mathrm{mm}$ respectively. The material having higher stiffness ratio is stiffer materials than others. Stiff material can take more loads at a particular settlement installed in soft clayey-silt soil. That is why stone dust column carries more loads than pond ash column. The improvement of soft clayey-silt soil using column made of pond ash is less because of low density of pond ash and also as the weight of individual particles in pond ash less. Ultimately it is observed that in case of clayey-silt soil with either column made of pond ash or stone dust, load carrying capacity of soil increases, irrespective of size of loading plates.

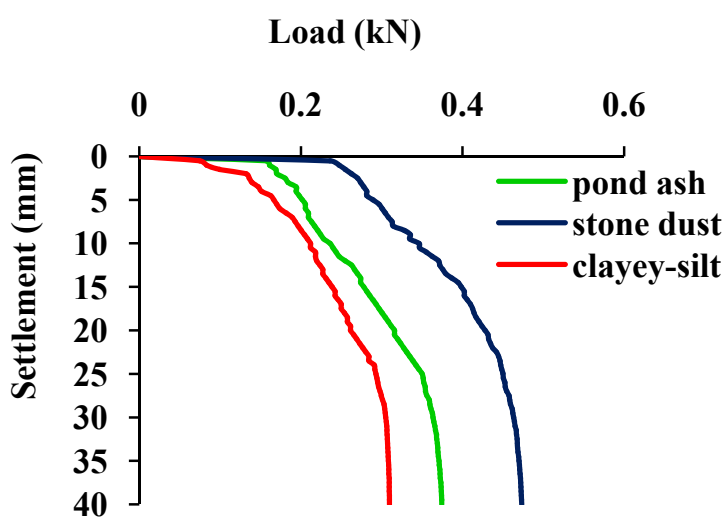

(a) Plate diameter $20 \mathrm{~mm}$

\section{$\operatorname{Load}(\mathbf{k N})$}

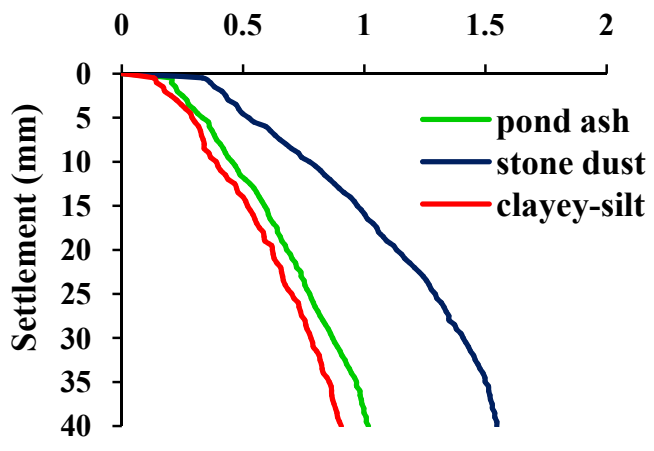

(b) Square plate size $300 \mathrm{~mm} \times 300 \mathrm{~mm}$

Fig. 5. Typical diagram for influence of material on load-settlement behavior for single column of 20 mm diameter for different plate size

\section{B. Effect of size of loading plate on columns}

The diameter of the loading plate affects the load-settlement behavior of the clayey-silt soil. Load is applied through the plate having the diameter of column, twice the diameter of column and over whole area of the testing tank on pond ash and stone dust column installed in soft clayey-silt soil. By varying the plate size through which load is applied on soil-column system, loading condition of the model test has changed. At different loading condition bulging effect of column, load carried by column at different settlement, effect of diameter and materials of column on load-settlement behavior of soil-column system are studied. Figure 6 shows the effect of loading plate on load-settlement behavior of soil-column system. It is noticed that the larger loading plate offers more load at any settlement than the other plate. Load over entire area for column of pond ash and stone dust shows maximum load carrying capacity. It is due to contact area between loading plate, columns and surrounding soils. Large size plate contacts more surface area of soil-column system in testing tank than the plate equal to column diameter which is in smaller size. In case of plate of diameter d, load is applied on column only where as for plate of diameter $2 \mathrm{~d}$, not only the column but the surrounding soil also takes the load. That is why load obtained in case of plate diameter $2 \mathrm{~d}$ is higher than the $\mathrm{d}$. For same reason, maximum load for same materials at same settlement is obtained using the plate size of $300 \mathrm{~mm} \times 300 \mathrm{~mm}$. 


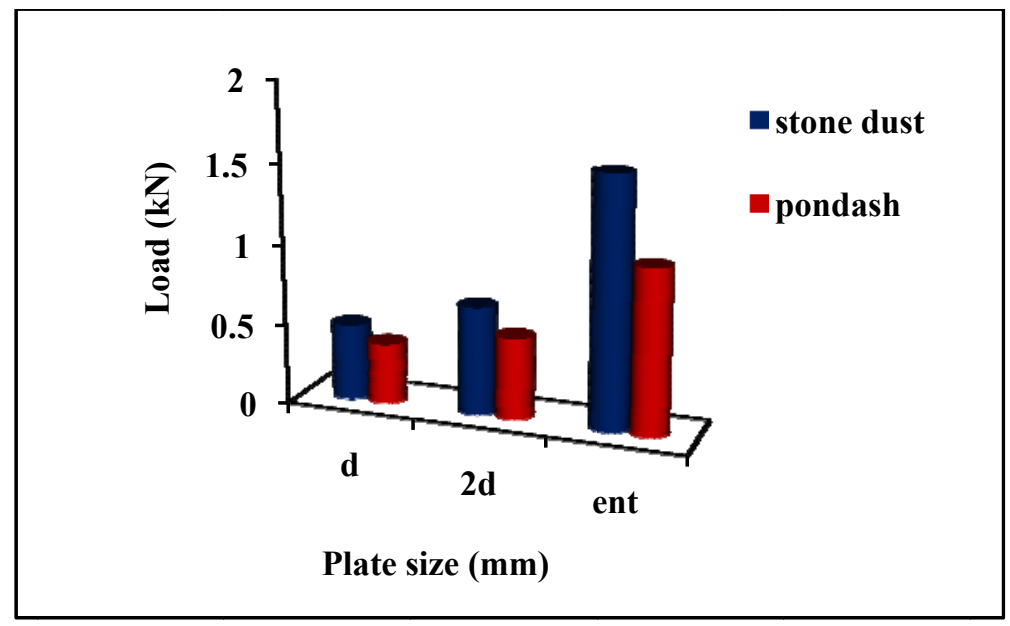

Fig. 6. Influence of size of loading plate on single column of different materials

\section{Failure Surface}

Load on soil-column system causes failure of column through bulging. This bulging action of the column is effective for a certain depth of column installed in soft clayey-silt soil. Bulging depth (i.e., the depth up to which column bilges) varies within the range of $0.3 \mathrm{~d}-0.7 \mathrm{~d}$, where $\mathrm{d}$ is the diameter of column. Reference [2] found out $0.5 \mathrm{~d}$ bulging depth for stone column of $100 \mathrm{~mm}$ diameter installed in soft clay. Figure 7 shows the typical bulging of single column of materials. Similar type of bulging pattern was observed by [6] on stone column in soft and loose layered sandy-silt with clayey soil and [12] on stone column in layered soil. For entire area loading, bulging of single column surrounding soft clayey-silt soil is not significant and is shown in Fig. 8. No bulging is noticed when the entire tank area is loaded as [1,2 and 13]

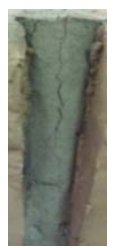

stone dust column for loading plate of $20 \mathrm{~mm}$ diameter

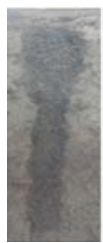

pond ash column for loading plate of $20 \mathrm{~mm}$ diameter

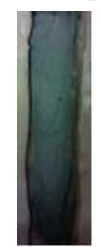

stone dust column for loading plate of $40 \mathrm{~mm}$ diameter

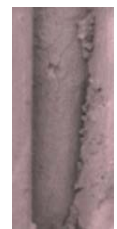

pond ash column for loading plate of $40 \mathrm{~mm}$ diameter

Fig. 7. Bulging of single columns of different materials and loading plates

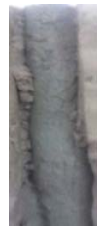

pond ash column

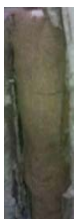

stone dust column

Fig. 8. Bulging of single columns of different material for entire area loading

\section{Effect of water content on consolidation of clayey-silt soil}

Consolidation test of clayey-silt soil is carried out both at OMC obtained by standard Proctor compaction and liquid limit to study the effect of water content on consolidation behavior. In the soil particles number of voids filled by water is more at liquid limit compare to the water content at OMC. Slope of the virgin curve is directly proportional to the void ratio. More the void ratio stiffer the virgin slope i.e., settlements occur quickly. The e$\log \mathrm{p}$ curve for clayey-silt soil both at liquid limit and OMC are shown in Fig. 9. It is clearly seen that slope of virgin curve at $\mathrm{OMC}$ is milder than virgin curve of clayey-silt soil at liquid limit. $\mathrm{C}_{\mathrm{c}}$ value depends on the slope of the virgin curve which varies with water content. On the other hand quantity of water that is expelled out from the voids in clayey-silt soil is more at liquid limit. Under loading condition it is easy to expel out these water from the voids in soil at liquid limit within a short time and soil sample settles quickly than soil at OMC. Due to this phenomenon compression index of clayey-silt soil at liquid limit (i.e., 1.606) is increased than clayey-silt soil at OMC (i.e., 0.227). 


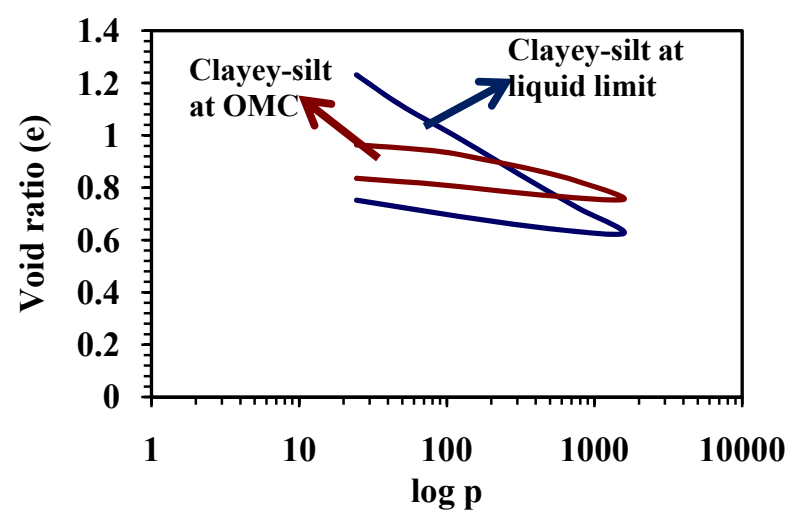

Fig. 9. Effect of water content on consolidation of clayey-silt soil

\section{E. Effect of column on settlement of clayey-silt soil}

It is observed that pond ash column installed in soft clayey-silt settles more as compare to stone dust column. Stone dust is poured into soft clayey soil in dry condition to form the column of $20 \mathrm{~mm}$ diameter where as the water content of the surrounding soil is $45 \%$ (i.e., liquid limit). stone dust helps to expelled out the water from voids of the surrounding soft clayey-silt soils quickly than pond ash as void ratio of stone dust is more than that of pond ash and clayey-silt soil (table 1). Figure 10 shows the e-log p curve for pond ash and stone dust column installed in soft clayey-silt soil.

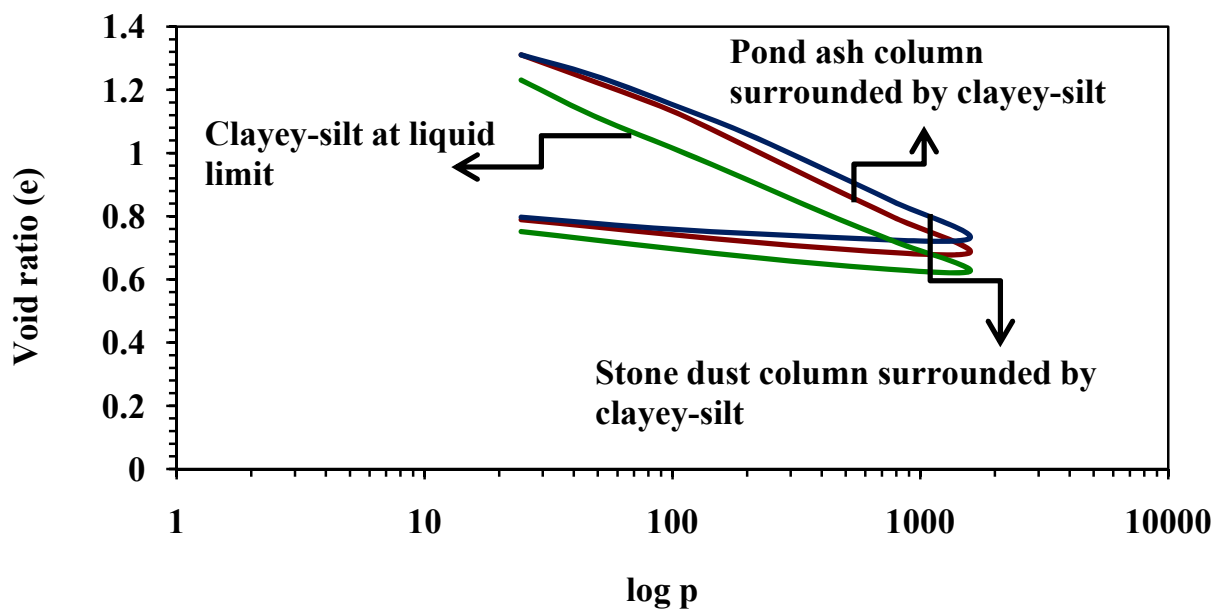

Fig. 10. Effect of pond ash and stone dust column on consolidation of clayey-silt soil

F. Effects compression index and coefficient of consolidation on column installed in soft clayey-silt soil

$\mathrm{C}_{\mathrm{c}}$ value of clayey-silt soil is higher than that of pond ash and stone dust column as shown in Fig. 11(a). This is because of inserting the stiff material into the soil compare to the surrounding soft clayey-silt soil. Pond ash is stiffer than soft clayey-silt soil and stone dust is stiffer than pond ash. Due to $\mathrm{C}_{\mathrm{c}}$, values, settlement of the stone dust column installed in soft clayey-silt soil is smaller than the pond ash column and than that of soft clayey-silt soil. Coefficient of consolidation $\left(c_{v}\right)$ also effect the settlement of soft clayey-silt soil. Figure 11(b) shows the effect of $c_{v}$ on soft clayey-silt soil, pond ash and stone dust column installed in soft clayey-silt soil. As $c_{v}$ increases time required for settlement decreases. Because of stiffer material and more voids in particles, stone dust settles within a short time than pond ash and soft clayey-silt soil. On the other hand the individual particles of pond ash is thin and light in weight and cannot expelled out the water from surrounding soft clayey silt soil easily than that of stone dust; take more time to complete the consolidation process compare to stone dust column. soft clayey-silt soil take maximum time to consolidate as the particles are fully saturated and there is no additional material in to it to help in flow of water. $c_{v}$ value is higher for clayey-silt soil with stone dust column than that of pond ash column and soft clayey-silt soil without column. 


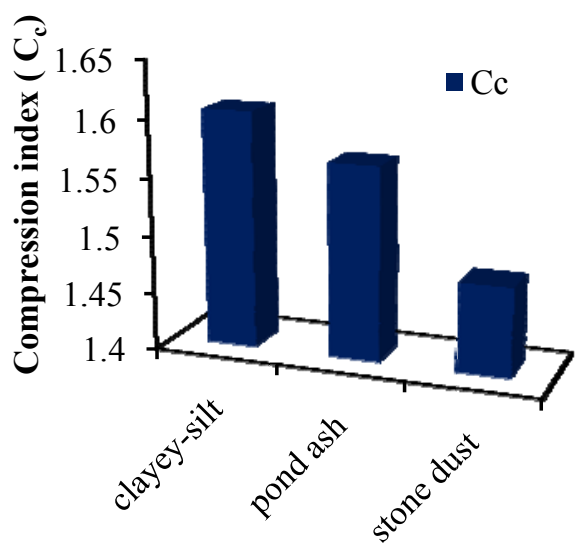

Materials

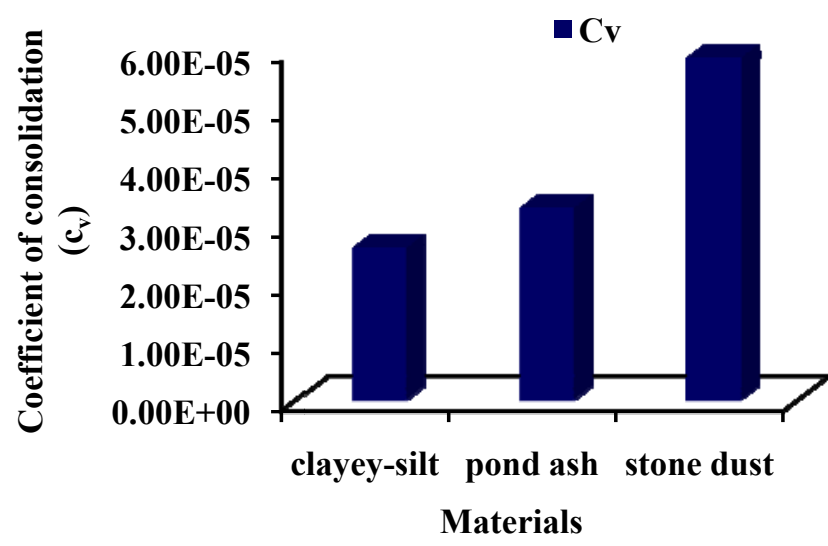

(b)

(a)

Fig. 11. Effect of consolidation characteristics on column installed in soft clayey-silt soil

\section{PRACTICAL IMPLICATION}

To improve the bearing capacity of waste water land, paddy land or similar lands with soft soils and settlements are within permissible limits, installations of stone dust and pond ash columns are found to be effective and economical. Stone dust column acts as stiff reinforcing element into the soft soil and provide comparable strength. Pond ash column may be used for small structure in water or paddy land. Based on the result from load-settlement test it is found that soft clayey-silt soil along with pond ash and stone dust column can carry 7.05-21.04\% , and 53.07-62.84\% higher load respectively than soft clayey-silt soil of this study. If proper design and construction procedures are followed stone dust column may used for small embankment, culverts, rural roads etc. and thus environmental requirements are also fulfilled.

\section{SUMMARY AND CONCLUSIONS}

Based on the results and discussions made on single columns of different materials installed in soft clayey-silt soil following conclusions may be made:

1. Load carrying capacity for stone dust (passing through 600 micron) column is maximum than pond ash column.

2. Clayey-silt soil with stone dust column can carry more loads than pond ash column and clayey-silt soil without column but clayey-silt with pond ash column can carry $7.05-21.04 \%$ more load than ordinary clayey-silt soil.

3. The void ratio of the pond ash is also higher than clayey-silt i.e., pond ash helps in drainage also.

4. Column bulges within a depth of $0.3 \mathrm{~d}$ to $0.7 \mathrm{~d}$ for pond ash and stone dust column.

5. No significant bulging is observed in column of pond ash and stone dust when column is loaded on entire area of the testing tank.

6. The value of coefficient of consolidation is small for soft clayey-silt soil than that of pond ash and stone dust column installed in soft clayey-silt soil.

7. The water content of soil sample affects the consolidation settlements of that soil sample. Soil having higher water content settles more than at lower water content.

\section{REFERENCES}

[1] Ambily A. P., and Gandhi S. R., "Experimental and theoretical evaluation of stone column in soft clay," International Conference on Geomatics and Geological Engineering, pp. 201-206. 2004.

[2] Ambily, A. P., and Gandhi, S. R., "Behavior of Stone Columns Based on Experimental and FEM Analysis," American Society of Civil Engineers, ASCE J. for Geotechnical and Geoenvironmental Engineering, 133(4) 405-415. 2007.

[3] Bhattacharyya, A., and Pal, S.K., “A study of single stone column,” Indian Geotechnical Conference IIT Delhi, 2012, Vol. 1, pp. 612615.

[4] Black, J. A., Sivakumar, V., Madhav, M. R., and Hamill, G. A., "Reinforced Stone Columns in Weak Deposits: Laboratory Model Study," American Society of Civil Engineers, ASCE J. for Geotechnical and Geoenvironmental Engineering,133(9) 1154-1161. 2007.

[5] Charles, J. A., and Watts, K. A., "Compressibility of soft clay reinforced with granular columns," Proceedings of the 8th European conference on soil mechanics and foundation engineering, Helsinki, 1983, pp. 347-352.

[6] Das, P., and Pal, S. K., "Study of the Behavior of Stone Column in Local Soft and Loose layered Soil," Electronics Journal of Geotechnical Engineering. 2013.

[7] Gniel, J., and Bouazza, A., "Improvement of soft soils using geogrid encased stone columns," Geotextiles and Geomembranes. Elsever. 2009.

[8] Hughes, J. M. O., and Withers, N. J., "Reinforcing of soft cohesive soils with stone columns,”Ground Eng., Vol. 7, No. 3, pp. 42-49. 1974. 
[9] Hughes, J. M. O., Withers, N. J., Greenwood, D. A., "A field trial of the reinforcing effect of a stone column in soil," Geotechnique, Vol. 25, No. 1, pp. 31-44. 1975.

[10] Murugesan, S., and Rajagopal, K., (2008). "Performance of encased stone columns and design guidelines for construction on soft clay soils," Proceedings of the 4th Asian Regional Conference on Geosynthetics Shanghai, China.

[11] Murugesan, S., and Rajagopal, K., "Studies on the behavior of single and group of geosynthetic encased stone columns. American Society of Civil Engineers," ASCE J. for Geotechnical and Geoenvironmental Engineering, 136(1) 1943-5606. 2010.

[12] Rao, N. S., Prasad, Y. V. S, Rao, H. V., "Use of stone columns in soft marine clays," Proceedings of the 45th Canadian geotechnical conference, 1992, pp. 9/1-9/7.

[13] Shivashankar, R., Babu, D. M. R., Nayak, S., and Manjunath, R., "Stone columns with vertical circumferential nails: laboratory model study," Geotech Geol Eng., Springer, Vol. 28, pp. 695-706. 2010.

\section{AUTHORS PROFILE}

Sadrita Dutta has born on 31-12-1987 and obtained B.E.in Civil Engineering from National Institute of Technology Agartala, Tripura, India in 2010 and M.Tech in Geotechnical engineering from National Institute of Technology Silchar, Assam, India in 2012. Presently she is pursuing her PhD from NIT Agartala, Tripura, India. Her area of research is ground improvement technique. She has published papers in international journals and national conferences.

Dr. Sujit Kumar Pal is presently working as Associate Professor in Civil Engg., NIT, Agartala, Tripura, INDIA. Completed BE (Civil Engg.) from REC, Surathkal, Karnataka, INDIA (Presently, NIT, Surathkal) in 1986 and M. Tech (Soil Mech. \& Foundation Engg.) from IIT, Khragpur, West Bengal, INDIA in January, 1993. He has completed his Ph.D (Engg.) from Bengal Engineering and Science University, Shibpur, West Bengal, INDIA (Presently, Indian Institute of Engineering Science and Technology, Shibpur) in January, 2010. $\mathrm{He}$ has a wide range of publications in national and international Journals and conferences like, ASCE, SPRINGER, EJGE, IJRET, IGC, DFI etc. His present research areas are soil characterization, soil dynamics, ground improvement, shallow and deep foundations and soil-structure interaction. His teaching experience is more than 30 years and actively engaged in teaching, research and consultancy works. 